\title{
HISTOLOGICAL CHANGES INDUCED IN THE MUCOUS GLAND AND THE BODY WALL OF SMALL SAND SNAIL Helicella vestalis TREATED WITH DIMETHOATE AND BENOMYL INSECTICIDES.
}

Al-Akraa, T. M. M.

Agric. Zoology and Nematology Dept., Fac. of Agric., Al-Azhar Univ.

\begin{abstract}
The present study aimed to illustrate the some histological impact of Dimethoate and Benomyl compounds on the mucous gland and the body wall of Helicella vestalis at $0.25 \%$ level after 24 hours post treatment

Mucous gland: Tufted tubular and assemble of mucous gland branches were shaped by the effect of $0.25 \%$ Dimethoate in mucous gland of H.vestalis after 24 hours post treatment, at the portion time, the amount of mucous exuded decreased with increase in volume of mucous cells. Also, effect of Benomyl in mucous gland were coherence of the branches of the mucous gland vast led to the exsiccation of land snail and its death, and increase in the mucous cell volume with certain change in the color and it had been isolated and had no integration with each other.

Effects of Dimethoate on body wall of H.vestalis led to presence of a large apertures resolving on the semblance of leather wide, lessening the amount of mucus excreted, while $0.25 \%$ Benomyl clearly showed no apertures on the integrement appearance wide.

Keywords: Histological changes, mucous gland, small sand snail, Dimethoate and Benomyl.
\end{abstract}

\section{INTRODUCTION}

Land snails have become one of the most dangerous crop pests. They have direct bad effect resulting from feeding on plant and daily activity. Many agriculture processes helped spreading land snails in rural areas of Egypt. In the past, they existed only in the Northern Coast .

On the other hand, the rapid adaptation to the different places played an important role in this respect (Asran, 2001 and Ibrahim, 2010). Moreover, it was necessary to use toxic chemical compounds to eliminate these pests. Several histological and biochemical studies were carried out to determine certain enzymes as well as the histological changes resulting from the toxic treatment to explain how much those land snails affected (Fouad et al., 2004).

The present work was carried out to study some histological changes of the mucous gland and body wall of the small sand snail Helicella vestalis treated by Dimethoate and Benomyl at adult stage.

\section{MATERIALS AND METHODS}

\section{Tested animals:}

Individual's adult snail of Helicella vestalis were collected from different infested nurseries at Alexandria governorate. Mean shell diameter of selected animals was $<8 \mathrm{~mm}$. Healthy individuals snail were kept separately in a 
small plastic boxes containing $8-10 \mathrm{~cm}$, moist optimal soil (clay, peat and sand at 1:1:1) provided with fresh green lettuce leaves, covered with muslin secured with rubber band to prevent snails from escaping (Zidan et al., 2001 and Al-Akraa, 2005), and kept under the ideal laboratory conditions, i.e. of 22 $\pm 2 \circ \mathrm{C}$ and $80 \pm 5 \%$ R.H .

Chemical insecticides used:

a) Dimethoate $50 \%$ EC phosphorus compound, at the concentration of $0.25 \%$. chemical name: 0.0 . dimethyl 5 - (N-methyl carbamoly - methyl). Phospharodimithoate, ( Target Inovation Company TIC- Lebanon.)

b) Benomyl $50 \%$ W.P, a carbamate compound, at the concentration of $0.25 \%$. Chemical name: methyl 1 - (butylcarbamoul) -2- benzimida zolecarbamate, ( Target Inovation Company TIC- Lebanon.)

\section{Chemical treatments:}

The two tested compounds were prepared just before application. Appropriated amount of each compound was diluted with water to obtain the required concentration (Ghamry, 1997).

Fresh lettuce leaves were sprayed with the candidate compounds and were offered to the maintained land snail species after 24 hs starvation (Abd El-Karim, 2000 and Haleim, 2007).

Five replicates were prepared for each treatment in addition to another one left with each treatment as a check control (Fouad, 2002 and Khalifa, 2009).

All groups of treated and untreated snail were examined for their mucous gland and body wall.

Anatomical and histological studies:

To observe the gross morphology of the soft parts of $H$. vestalis, these were anaesthetized in $1 \%$ solution of choral hydrate for 12 hours. The shell was then removed and the soft parts were fixed with $10 \%$ formalin for at least 24 hours. Soft parts were progressively dissected with the help of binocular dissecting microscope. The mucous gland and the body wall of the treated snails were carefully removed, photographed and compared with those of untreated (Shoieb, 1997). Histological preparation were investigated by light microscopy. The soft parts of the snails were directly immersed in Bouin's solution for fixation (Cowie, 1984). Small tissues representing different regions of both the mucous gland and body wall were washed, dehydrated, cleared and finally embedded in Paraffin wax. Sections were cut 6-8 microns in thickness, mounted on glass slides and stained with Haematoxylin and Eosin photomicrographs (x40) were taken for both mucous gland and body wall and compared with those of untreated snails (Mersal, 1990).

\section{Mucous gland:}

\section{RESULTS AND DISCUSSION}

Generally untreated mucous gland appears ol that tufted tubular mucous gland had much branched and resemble little brunches of whitish sea- weed (Fig 1). The secretory cells forming the wall of the tubules were tall columnar cells containing the secretory granules. The secretory cells were arranged around irregular lumen (Fig 2). 


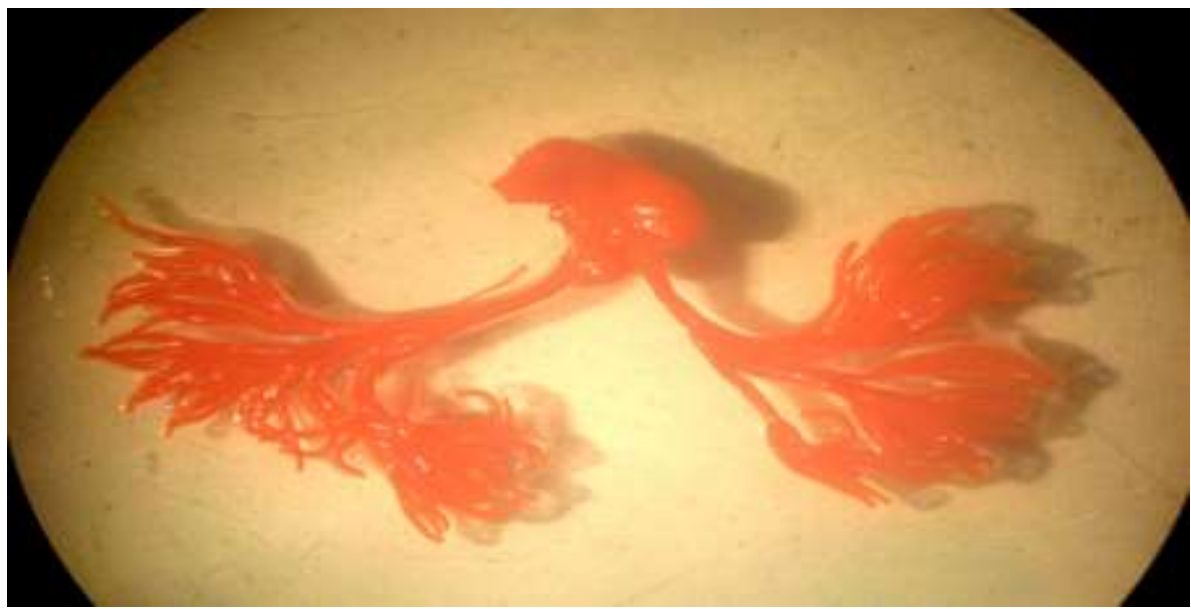

Fig. (1):Mucous gland of H.vestalis in control group.

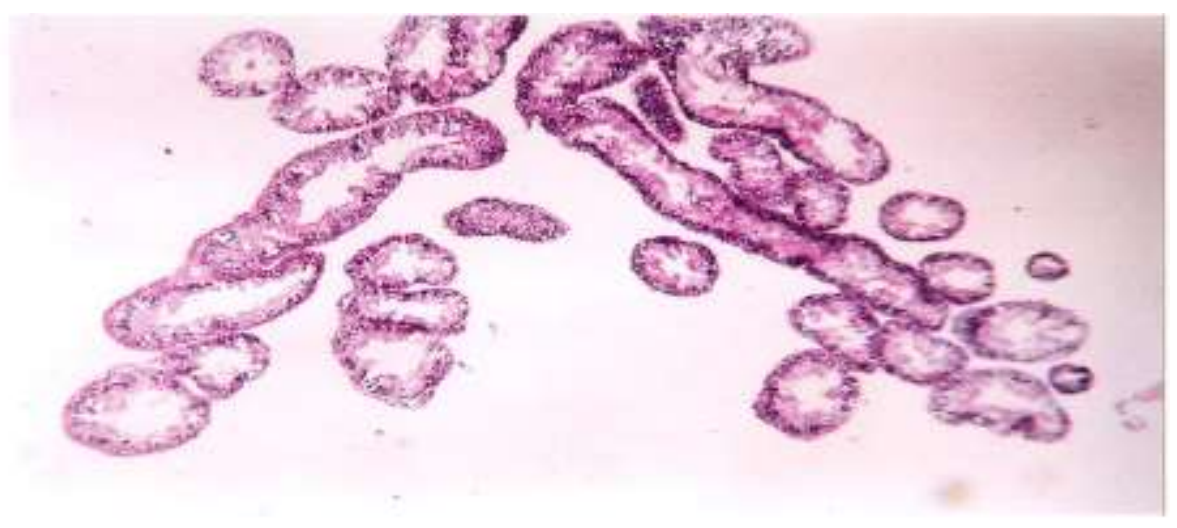

Fig. (2):Mucous cells of $\boldsymbol{H}$.vestalis in control group.

Histological changes in mucous gland after 24 hours post treatment with $0.25 \%$ Dimethoate were shown in Fig (3). It can be seen clearly the complete adhesion of tufted tubular and wide reduce the quantity of mucous secreted to protect of $H$.vestalis.

Fig (4) that increase in the volume of cells and figures have been irregular, while effect of $0.25 \%$ Benomyl in 24 hours post treatment, there were cohesion and fusion of the branches of the mucous gland wide led to the desiccation of the land snail and its death and increase in the cell volume of mucous gland cells with some change in the colour and it had been lonely and had no combination with each other (Fig 4). The nature of mucous secretion on the body surface varies and were noticed by Cook and Shirbhate (1983).Which suggests different functions for mucous on different areas of the epithelium. Luchtel et al. (1984) and (1991) found that the secretions are often voluminous, and produced by cell of the epithelium, particularly by the mucous and channel cells. 


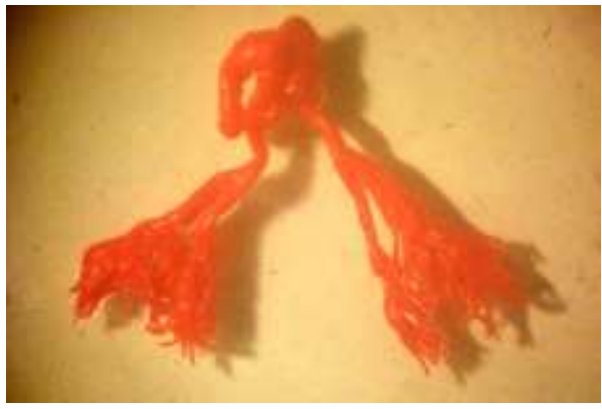

(A)

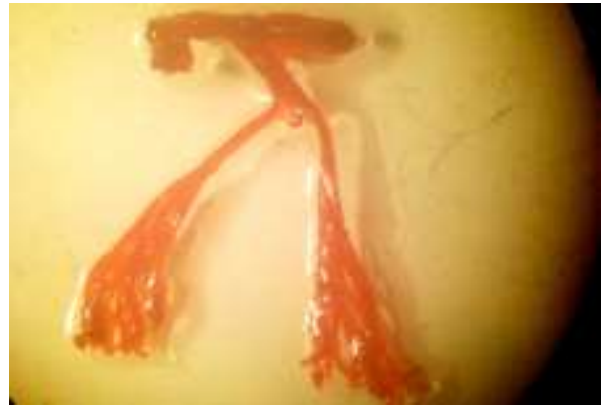

(B)

Fig. (3): Effect of Dimethoaite (A) and Benomyl (B) on mucous gland of H. vestalis

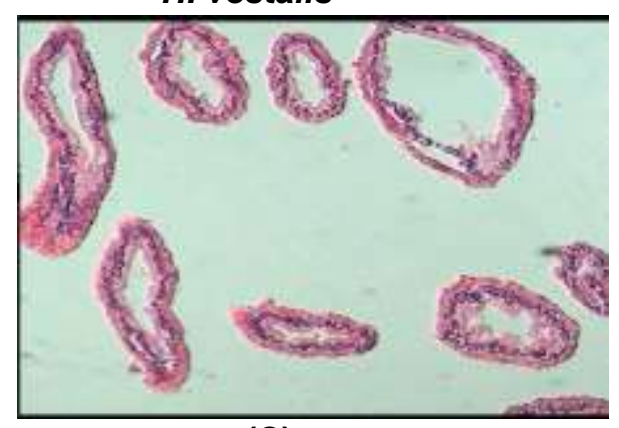

(C)

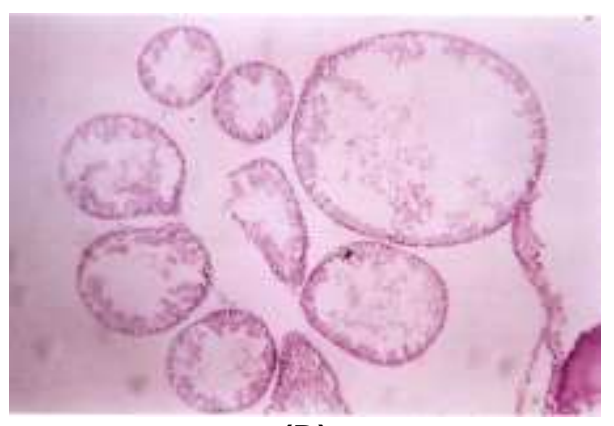

(D)

Fig. (4): Effect of Dimethoaite(C) and Benomyl(D) on mucous cells of $H$. vestalis (x40).

\section{Body wall:}

The epithelium is composed primarily of a single layer of two types of columnar to cubical-shaped cells (micro villous cells and ciliated cells). These two cell types are distinguished by the presence of micro villous and cilia on their apical surfaces, respectively. Also, the epithelium has large secretive cells (vacuoles), which extend into the matrix of muscle and connective tissue that make up the sub epithelial part of the body wall. These large cells include mucous cell, channel cells and calciferous cells (Fig. 5). Dimethoate compound induced histological changes on body wall of $H$. vestalis that illustrated in Fig. (5) showed presence of a large vacuole in instead of presence of some small vacuoles spreading on the surface of skin wide reduce the quantity of mucous secreted to protect the snail from the effect of the insecticides, so that led to a desiccation to the snail and its death. Also, Fig. (5) showed that, histological changes in body wall after 24 hours post treatment at $0.25 \%$ Benomyl, no vacuoles on the skin surface . 

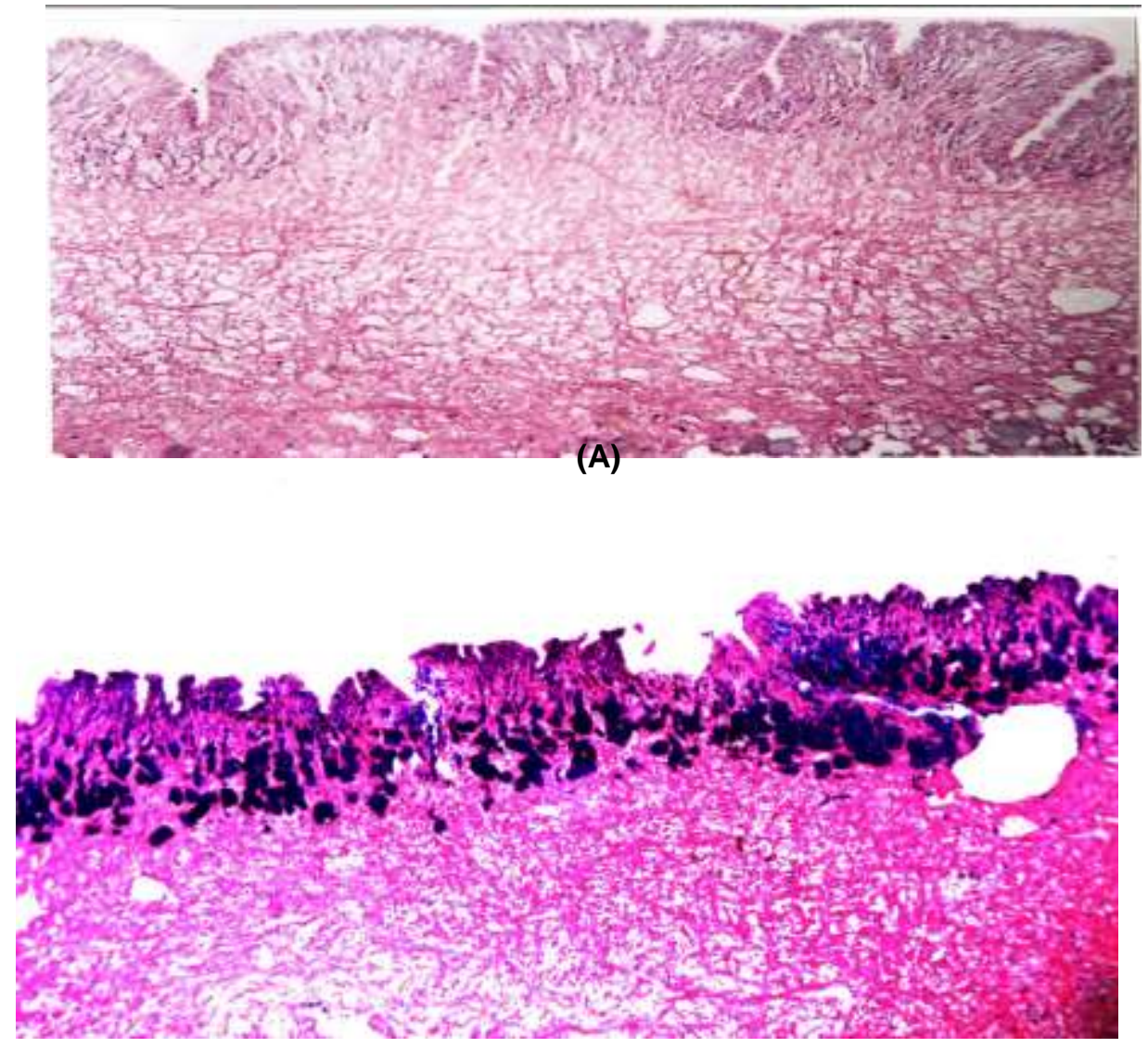

(B)

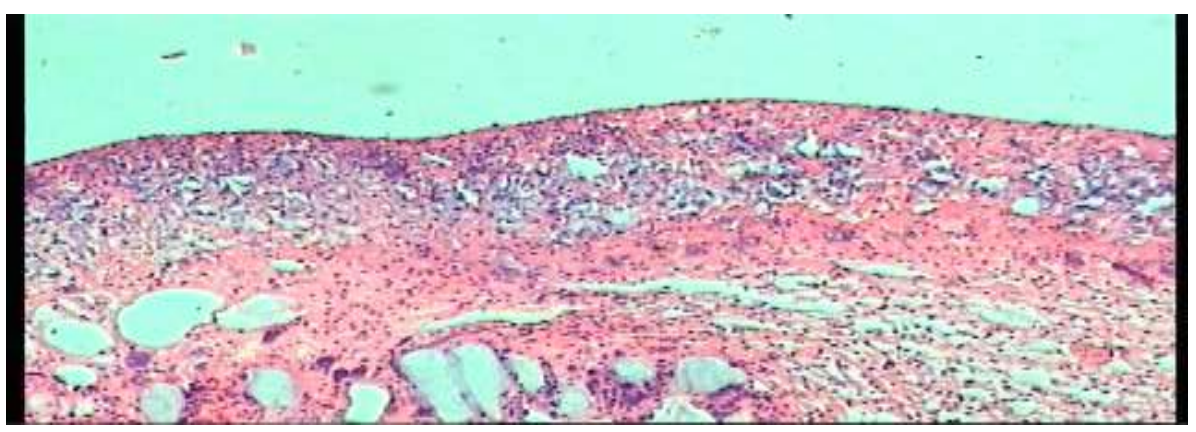

(C)

Fig. (5): Body wall of $H$. vestalis in control group $(x 40)(A)$, Dimethoate(B) and Benomyl(C) . 


\section{Al-Akraa, T. M. M.}

Generally results agree with Newell (1973and1977) who found that in terrestrial pulmonates, the skin is formed by an epithelium which is as well supplied with enzymes and mucous cells as the epithelium of vertebrate intestine. The skin of land snails contains special gland which secrete a covering of slim, which serves as a protection against desiccation. Also, the skin of land snails is important as the structure which is exposed to contact with insecticides.

Deyrup et al. (1996) showed that the release of mucous is accompanied by the rupture of mucous granules which is triggered by ATP. The observed reduction of energy reserves (lipid and glycogen) in the crop and the hepatopancreas may be related to this phenomenon.

\section{REFERENCES}

Abd-El-Karim, Nehmedo. (2000): Ecological and biological studies on some terrestrial African agricultural snail pests. M. Sc. Thesis, African Studies Institute, Cairo Univ., 123-133.

Al-Akraa, T.M.M. (2005): Studies on some land mollusca. Ph. D. Thesis, Faculty Agric, Al-Azhar Univ., 164.

Asran, Fawkyia, D. (2001): Evaluation and implementation of novel and environmentally safe approaches in IPM for terrestrial snails. Ph.D. Thesis, institute of environs. Studies Res., Ain Shams Univ., 199.

Cook, A. and Shirbhate, R. (1983): The mucous producing glands and distribution of cilia of the pulmonate slug, limax psedoffavues. Journal of Zoology, 201: 97-116.

Cowie, R. (1984): The life cycle and productivity of the land snail Theba pisana (Mollusca: helicidae). J. Animal Ecol., $53: 311-326$.

Deyrup, Olsen, I. and Jindrova, H. (1996): Product release by mucous granules of land slugs: Ariolimax columbianus as a model species. Journal of Exponential Zoology, 276:387-393.

Fouad, Maha, M. (2002): Effect of neem extract. Garlic acid and diflubenzuron on jaws morphology of some terrestrial mollusks. Egypt.J.Agric. Res., 80 (1): 155-167.

Fouad, Maha,M.; Khider, Fatma,K; Ibrahim, I.K. and Soliman, A.M.A. (2004): Laboratory studies on the molluscicidal effect of sumithion, bindio card and machete pesticides against tree land snail species. J. Agric. Sci. Mansoura Univ, (1): 451-455.

Ghamry, E.M. (1997): Bioassay for two strains of bacteria Bacillus thuringiensis against certain land snails, under laboratory conditions. Egypt. J. Appl. Sci., 12(5): 661-672.

Haleim, S.M.A. (2007): Ecological and toxicological studies on some land snails infesting cotton and clover crops. M. Sc. Thesis, Faculty Agric., Cairo Univ., p.122.

Ibrahim, M.A.D. (2010):Toxicological and biological studies on some terrestrial snails and slugs at Dakahlia governorate. Ph. D. Thesis, Faculty of Agric., Al-Azhar Univ., 161. 
Khalifa, R.F. (2009): Studies on some common land snails and slugs on certain horticultural crops in Minufiya governorate. M. Sc. Thesis, Faculty Agric., Minufiya Univ., p.125.

Luchtel, D.L. ; Deyrup-Olsen, I. and Martain, A.W. (1991): Ultrastructure and lysis of mucin containing granules in epidermal pulmonata. Cell and Tissue Research, 266: 375-383.

Luchtel, D. L. ; Martian, A.W. and Deyrup-Olsen. I. (1984): the channel cell of the terrestrial slug Aridimax columbianus. Cell and tissue Research 235: $143-151$.

Mersal, H.T.I. (1990): Morphological, anatomical and histological studies on some land snails of agriculture importance in Egypt. M.Sc. Thesis, faculty of Girls, importance in Egypt Ain Shams Univ., p.199.

Newell, P.F. (1973): Etude de l'ullrastructure de l'epithelium dorsal et pedieux des limaces Arion hortensis feussace Agriolimax reticulates (muller). Haliotis, 3:131-135.

Newell, P.F. (1977): The structure and enzyme histochemistry of slug skin. Malacologia, 16: 183-195.

Shoied, M.A. (1997): Ecological studies on some common snail species and their control in ismailia governorate. M.Sc. Thesis, Fac. Agric, Suez Canal Univ., 137.

Zidan, Z. H., El-deeb, H. I.; Shobeiha, A.K.; Setaita, Ahmed, H.; Fawkyia, Asran, D.A. and Maha, Fouad, M. (2001): Molluscicidal and antifeeding effects of certain plant extracts against three land snail species in Egypt. J. Environ. Sci. Institute of environmental studies and research. Ain shams university. 2(1): 57-74. 
Al-Akraa, T. M. M.

التـأثير الهستولوجى لمبيدي الدايمثيوث والبينوميل على الغدة المخاطيـة وجدار

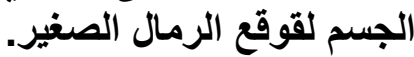
طارق محمد مصطفى الأقرع المقعي قسم الحيوان الززاعي والنيماتودا- كلية الزراعة. جامعة الأزهر - القاهرة.

الهدف من البحث هو المقارنة بين تأثير مبيد كارباماتي (البينومل) ومبيد

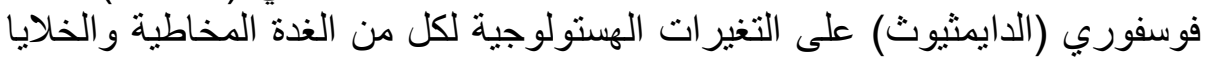

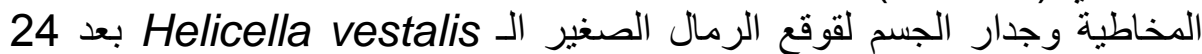

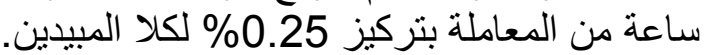
وكانت النتائج المتحصل عليها كالآتي: -

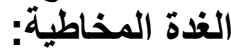

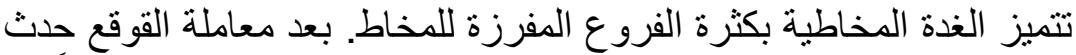

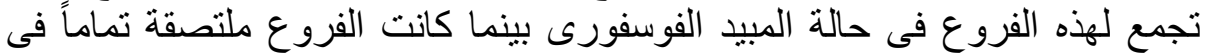

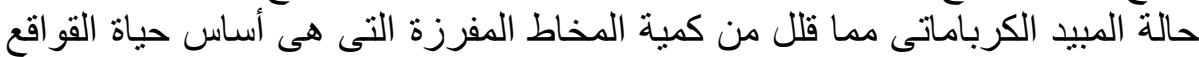

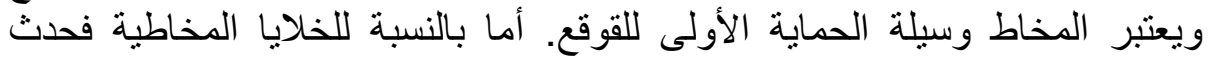

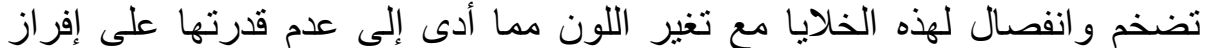

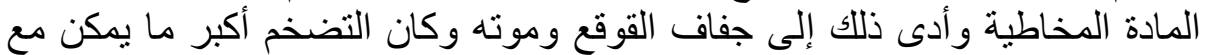
المبيد الكرباماتى (اليينوميل) عنها فى حالة المبيد الفوسفوري (الدايمثيوث).

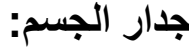

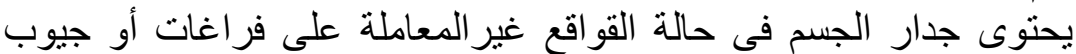

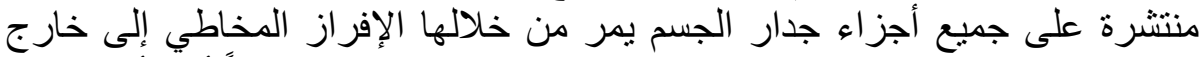

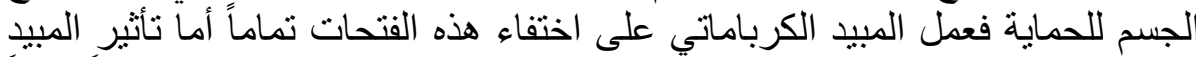

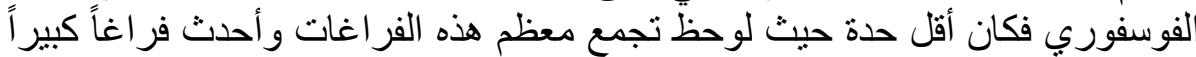
مما أدى إلى خلل فى توزيع إفراز المادة الدخاطية على سطح الجسم وبالتالي جفاف

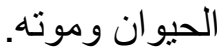
قام بتحكيم البحث

كلية الزراعة - جامعة المنصورة كلية الطب - جامعة الأزهر

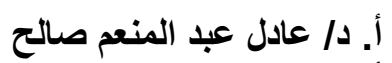

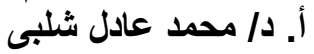


J. Plant Protection and Pathology, Mansoura Univ., Vol.1(9), September, 2010 
Al-Akraa, T. М. M. 